\title{
Kvinner i diplomati og internasjonal politiklk
}

\section{Women, Diplomacy and International Politics since 1500 \\ Glenda Sluga og Carolyn James (red.) \\ Routledge, 2016}

\section{Women of the World. The Rise of the Female Diplomat}

\section{Helen McCarthy}

Bloomsbury, 2014

Anmeldt av Halvard Leira ${ }^{\star}$, Cand. polit., Seniorforsker, NUPI

\section{Innledning}

Hvor er kvinnene? Dette spørsmålet har vært et av utgangspunktene for flere tiår med kvinnestudier i humaniora og samfunnsfag, etter hvert kjønnsstudier, der det slående ofte har vist seg at kvinnene har vært til stede hele tiden, det har bare ikke vært noen (menn) som har brydd seg om å lete etter dem. Innenfor diplomatistudier er de bøkene som vurderes her blant de første som reiser spørsmålet på systematisk vis.

I studiet av internasjonal politikk har forskjellige former for studier av kvinner og kjønn vært viktige siden 1980 -tallet, men med relativt kort historisk horisont. Langt på vei har studier av kvinner vært begrenset til den historiske perioden der likestilling ut over stemmerett for alvor kom på dagsorden; den andre feministiske bølgen fra 1960-tallet og fremover. Kvinneperspektivene har også ofte vært rettet mot emner som har blitt oppfattet som perifere innenfor fagets klassiske teorier. Historiefaget tok opp kvinneperspektiver tidligere, men der falt interessen for kvinner og kjønn i stor grad sammen med den sosialhistoriske vendingen. Internasjonal historie og diplomatisk historie forble relativt upåvirket, om noe bidro kiønnsperspektiver til å styrke bildet av diplomatiet som en maskulin geskjeft og «high politics» som et mannlig felt. I sine beste øyeblikk undergraver de to bøkene som vurderes her enkle forestillinger om strikte mannlige og kvinnelige sfærer innenfor diplomati og internasjonal politikk, og det er lov å håpe at de vil være med på å bidra til at historien om det moderne diplomatiet skrives på nytt.

^Korrespondanse: Halvard Leira, NUPI. Email: hl@nupi.no 
To overordnede spørsmål til bøker som dette, er om og hvordan kjønn har hatt en effekt, i dette tilfelle på diplomati. For å spesifisere litt kan vi tenke oss tre muligheter: at kvinner har spilt en rolle innen diplomatiet i kraft av sitt kjønn, at kvinner har spilt en rolle innen diplomatiet på tross av sitt kjønn og at kjønn i seg selv ikke har hatt noen effekt på hvilke roller kvinner har spilt i diplomatiet. Det er all grunn til å tro at det siste alternativet ikke er spesielt relevant. Derimot er det nyttig å skille mellom de to første. For det er noe ganske annet å si at kvinner har lyktes i diplomatiet (eller i andre sammenhenger) til tross for sitt kjønn - underforstått at de har lyktes på menns premisser - og å si at de har lyktes i kraft av sitt kjønn. Det er fullt mulig at en og samme kvinne kombinerer de to elementene. For eksempel er det rimelig å hevde at Elisabeth I av England både var monark på tross av sitt kjønn, og at hun i sitt diplomatiske virke oppnådde resultater i kraft av sitt kjønn, for eksempel ved sine stadig pågående forhandlinger om mulig giftemål. Begge fenomenene er naturligvis interessante, men de åpner opp for forskjellige perspektiver. Kvinner som har lyktes på grunn av sitt kjønn kan være med på å antyde diplomatiske former og praksiser som tidligere har vært ignorert, mens kvinner som har lyktes på tross av sitt kjønn kan være med på å fortelle en bredere historie om kvinnefrigjøring og likestilling.

Begge disse bøkene ville ha vært tjent med en klarere diskusjon av denne typen problemstillinger, og de er sterke på hvert sitt felt. Ved å peke på kvinner som har spilt en rolle innen diplomatiet i kraft av sitt kjønn, åpner den redigerte boken til Sluga og James opp helt nye perspektiver på diplomati som sosialt fenomen. McCarthy presenterer for sin del i større grad en historie om hvordan kvinner gradvis trådte inn i den mannlige diplomatiske verden, om hvordan kvinner kunne lykkes på tross av sitt kjønn, og gradvis være med på å omdanne institusjonene de virket innen. Kronologi og fokusforskjell tilsier at de to bøkene diskuteres hver for seg, med en samlende konklusjon til slutt.

\section{Diplomati i et nytt lys}

Som bok betraktet er ikke Women, Diplomacy and International Politics since 1500 umiddelbart vellykket. Den bærer preg av å ha rot i workshops og seminarer, og å være satt sammen etter prinsippene om at «alle skal med», og at 500 år skulle dekkes. Kapitlene spriker i litt forskjellige retninger, de trekker på varierende litteraturer og med unntak av at de alle omhandler kvinner, er tematikken ganske variert. Introduksjonskapittelet til redaktørene setter riktignok scenen fint for de følgende kapitlene, men boken hadde fremstått som mye sterkere hvis den for det første hadde blitt delt i tre separate deler, for det andre hadde hatt et eksplisitt felles overordnet fokus og for det tredje hadde blitt avsluttet med et konklusjonskapittel. Når dette er sagt, så skal det straks kontres med at teksten er en fantastisk interessant artikkelsamling. Det store flertall av kapitlene er svært lesverdige, og de åpner til sammen opp helt nye måter å se diplomati på.

James og Sluga bruker innledningen for det første til å avgrense studieobjektet selv om samlingen favner vidt, så er den for eksempel unektelig eurosentrisk. Dermed speiler den i og for seg det moderne diplomatiet i stort (Neumann 2012), men som forfatterne også understreker, vil det være stor verdi i å utvide fokuset ytterligere. Videre trekker de også opp noen helt sentrale distinksjoner for å unngå anakronistiske 
lesninger. For eksempel påpeker de hvordan det vante og kjønnede skillet mellom en «mannlig» offentlig sfære og en «kvinnelig» privat sfære er et relativt nytt historisk produkt. Videre understreker de at det gir liten mening å studere både tidlig-moderne og moderne diplomati i lys av senere tiders nasjonale briller. Snarere fremstår en rekke forskjellige transnasjonale bånd som sentrale, ikke minst slektskap, men også felles kultur og praksiser. Ved inngangen til 1800-tallet bidro borgerskapets fremvekst til å utfordre mange av de nevnte trekkene, og gjorde diplomatiet betydelig mer kjønnet enn det hadde vært tidligere. Når bevisstheten om kvinnenes tidligere rolle har forsvunnet, kan det ha å gjøre med en helt konkret konsekvens av at skillet mellom privat og offentlig ble etablert på 1800-tallet; nemlig at brev forfattet av dronninger, prinsesser og hoffdamer av ivrige arkivarer ble skilt fra den offisielle korrespondansen, og dermed «usynlig» for historikerne.

Bokens første seks substanskapitler strekker seg fra rundt 1500 til det tidlige 1700tallet, men er alle i hovedsak konsentrert om sentrale kontinentaleuropeiske områder: Italia, Spania, Frankrike og Habsburgmonarkiet. En gienganger er også giftemålsstrategier og betydningen av kvinnelige slektskapsbånd. Kvinner som ble giftet bort bevarte på den ene siden bånd (og kanskje også lojalitet) til sin familie, men de var også uvurderlige kilder til kunnskap om hoffene de kom fra, så vel som fremmede språk og skikker. Slik kunnskap hadde de i høyere grad enn mange av sine samtidige menn. Kunnskapen ble også oppfrisket gjennom kontinuerlig brevveksling, som ofte kunne skaffe kvinnene informasjon som ikke kom frem gjennom vanlige diplomatiske kanaler.

Som flere av forfatterne understreker, var hoffene arenaer der både skillene mellom kjønnene og skillene mellom det private og det ikke-private var svakere enn ellers. Dette giorde at mange av de navngitte kvinnene som diskuteres var aktive partnere i sine menns aktiviteter, som dronninger eller fyrstinner, men også som koner til sendemenn. Samtidig muliggiorde den tvetydige posisjonen de hadde også at de kunne hevde uskyld og manglende kunnskap, hvis det var gunstig for politiske utfall. Hovedinntrykket er imidlertid av kvinner som i kraft av sin medfødte rang tok naturlig del i diplomatiske prosesser - de var rett og slett født inn i de kretsene der diplomatiske saker ble diskutert, $\mathrm{i}$ en tid der kjønn ikke var utslagsgivende for oppvekst på samme måte som senere.

Der menn stadig vekk ble kalt vekk for å delta i krig eller forhandlinger, var kvinnene oftest i mye større grad stedbundne. Det innebar at mange av dem kom til å virke som stedfortredere for sine menn, om de var fyrster eller sendemenn, med utstrakte fullmakter til å fatte bindende beslutninger. Det kontinuerlige nærværet ved hoffet, som også hoffdamene delte, ga også kvinnene en sentralitet i informasjonsnettverk som det er lett å overse i mer tradisjonelle fremstillinger. I tråd med en forståelse av kvinner som fredsvennlige, i motsetning til menns aggresjon, hadde kvinnene typisk sett betydelig diplomatisk innflytelse som konfliktløsere. Som Elena Woodacre påpeker i sitt kapittel, kunne Ferdinand av Aragon rundt 1500 «nekte å ta imot en fransk ambassadør, eller la være å bry seg om klagene fra en som klaget på at traktater ikke ble oppfylt. Brev fra Anne [fransk dronning og i et komplisert slektskapsforhold med Ferdinand] ville imidlertid bli mottatt, og hennes fint kalibrerte fraser kan ha vært mer effektive en noe en ambassadør kunne ha skrevet» (38). 
Den kanskje viktigste formen for konfliktløsning, eller i hvert fall symbolet på det, var giftemålet. Og i forhandlingene i forkant, spilte kvinnene i sentrale posisjoner en betydelig rolle. Som flere av bidragsyterne påpeker, er det også en misforståelse å tro at alt diplomati og alle allianser i perioden foregikk på «statsnivå», snarere foregikk det stadige forhandlinger adelen imellom, internt i forskjellige politiske enheter, og på tvers av grenser. Her deltok kvinnene aktivt, de kunne være førende i forhandlingene, og dere uformelle posisjon i diplomatiet gjorde dem spesielt fleksible og i stand til å spille på de tvetydighetene som var helt nødvendige i de ofte ganske delikate forhandlingene.

I sum viser disse seks kapitlene svært tydelig hvor sentrale kvinnelige aktører, kvinnenettverk og kvinner som både subjekter og objekter for diplomati var i fremveksten av moderne diplomati. De viser også hvordan kjønnsroller ikke var fastspikrede, men tvert imot ga rom for improvisasjon og bevisst tvetydighet. Sett $\mathrm{i}$ sammenheng med den fremvoksende litteraturen om slektskap (Fletcher \& DeSilva 2010; Johnson et al. 2011), som av uforståelige grunner bare er referert i et par av kapitlene, antyder disse kapitlene at vår forståelse av hvordan det moderne diplomatiet vokste frem og virket er modent for revisjon. Så lenge relasjonene mellom politiske enheter var inter-dynastiske heller enn internasjonale, kunne kvinnene, i kraft av å være de som ble giftet bort, være ekstremt viktige diplomatiske noder. I motsetning til ambassadører som kom og gikk, ble de oftest værende ved sine nye hoff livet ut, med privilegert tilgang til monarken. Betydningen av kronprinsesser, dronninger (og særlig de som var styrende eller regenter) og enkedronninger innebar også at andre kvinner kom i potensielt sentrale posisjoner; dels gjaldt dette deres mødre, søstre, kusiner og døtre, men også deres hoffdamer og konene til de mannlige ambassadørene. Når disse kvinnenes betydning stort sett har blitt ignorert både i diplomatisk historie og $\mathrm{i}$ teoretisering av diplomati som sosialt fenomen, skyldes dette trolig et ganske snevert fokus på traktater og andre offisielle dokumenter. Som disse forfatterne viser, gir andre kilder oss et helt annet syn, ikke bare på hvordan informasjon ble utvekslet, men også på hvordan traktater ble til og hvem de sentrale aktørene var. Det litteraturen før har fokusert på dramaet på scenen, bærer disse kapitlene buds om at en full forståelse av diplomati som sosialt fenomen også må ta inn over seg det som foregår i kulissene, bak scenen og på produksjonsmøtene. ${ }^{1}$ Som Silvia L. Mitchell (99) oppsummerer det fint: «The exclusion of women is, therefore, not a historical, but rather a historiographical problem. Unless we consider these women as integral parts of the system, the history of Europe will remain lamentably incomplete».

Som antydet over, var perioden mellom 1750 og 1850 en brytningsperiode av de sjeldne, med politiske revolusjoner, fremveksten av moderne ideologier, gryende industrialisering og gjennomgripende endringer i kommunikasjon og statlig organisering (Buzan \& Lawson 2015). Disse endringene hang også sammen med endringer i det politiske språket, både innenfor de enkelte statene (Koselleck 1988; Palonen 2006), og

\footnotetext{
${ }^{1}$ Her ville de nevnte kapitlene ha vunnet seg på engasjement med nyere IR-litteratur om diplomati. Betydningen av alt det som foregår rundt det «tradisjonelle» diplomatiet, er for eksempel sentralt hos Neumann (2013).
} 
i relasjonene mellom stater (Leira 2011, 2016). Kort fortalt ble «det internasjonale» begrepsfestet og kodifisert på måter det ikke hadde blitt før, med Wienerkongressens regulering av diplomatiet som det aller klareste eksempelet. I den samme perioden foregikk det også en betydelig endring i kjønnsroller og sementering av skiller mellom kjønnene, og skillet mellom det offentlige og det private begynte å anta de formene vi kjenner fra vår egen samtid. Det maskuline idealet hadde vært mannen som kunne kommunisere i salongene med de adelige kvinnene, men rundt 1800 endret det seg gradvis til den fysisk dominerende mannen som kunne kommandere andre menn (Towns 2014). Disse endringene hadde også rask konsekvens for diplomatiet, hvor menn for eksempel sluttet å ha ansvar for borddekking og menyer (Mori 2010), og ble mer orientert mot det som ettertiden husker som det «klassiske diplomatiet», med offisielle forhandlinger og møter. Menn i diplomatiet deltok i det som ble definert som den offentlige sfæren, mens det som ble definert som det private, som å holde orden på husholdet, ble kvinnenes rolle.

Denne grunnleggende endringen, som er godt beskrevet i annen litteratur, berøres stort sett bare indirekte hos Sluga \& James, med unntak av et lite avsnitt i innledningen og Slugas eget kapittel. Det er vanskelig å forstå denne mangelen, særlig ettersom flere av forfatterne eksplisitt nevner at en forutsetning for kvinners handlingsrom og handlekraft i tidlig moderne tid, var det uklare skille mellom privatsfære og offentlig sfære. Enhver leser vil oppleve en endring fra kapitlene som handler om hundreårene før 1800 og de som handler om perioden deretter, men denne endringen fremstår i de enkelte tekstene som nesten uforklarlig. Der kvinner, i kraft av sine uformelle posisjoner i en rekke nettverk, kunne spille på og overskride kjønnsroller i hundreårene før 1800, og dermed spille viktige diplomatiske roller, ble det ganske raskt etter 1800 svært mye vanskeligere å innta slike roller. En sterkere problematisering av denne endringen, ville både ha styrket artikkelsamlingen som intellektuelt produkt, og bidratt til en bedre forståelse av hvordan diplomatiet har kunnet fremstå som et så eksklusivt maskulint domene.

Av de tre kapitlene som dekker 1800-tallet, er Slugas om Germaine de Staël og Dorothea Lieven det mest interessante. Sluga skildrer med stor innsikt det vi kan kalle den siste fasen av salongdiplomatiet, der disse to kvinnene på uformell måte utførte mange av de funksjonene som vanlige diplomater utførte, men ofte med større innsikt og hell. Imidlertid er det også klart at de var utypiske, nærmest eksepsjonelle. Med borgerskapsidealene fulgte en periode der kvinnene ble mer og mer usynlige, og de to andre kapitlene i denne delen av boka presenterer kvinner som ikke hadde så stor innflytelse som de kunne ha ønsket seg, eller kanskje også burde hatt.

I sum viser disse kapitlene hvordan det ble stadig vanskeligere for kvinner å spille selv uoffisielle roller i diplomatiet ut over på 1800-tallet. Dette betyr naturligvis ikke at kvinnene forsvant fra diplomatenes liv, snarere tvert imot. Diplomatiets former var helt avhengige av kvinner som organiserte både hjem og selskapeligheter, og et riktig giftemål kunne virke sterkt karrierefremmende for en ung og fremadstormende diplomat, men disse formene åpnet i mye mindre grad enn tidligere for at kvinnene kunne spille selvstendige roller. Den gradvise kvinnefrigjøringen og likestillingen som kom på 1900-tallet, skjedde dermed mot den mest utfordrende bakgrunnen 
kvinnene hadde hatt siden moderne diplomati vokste frem. Og de rollene kvinnene hadde spilt i diplomatiet frem til omkring 1800, var stort sett glemt når kvinnene igjen forsøkte å finne en plass.

De seks gjenstående kapitlene er bokas mest ujevne, ${ }^{2}$ med analyser av kvinner i og rundt Folkeforbundet, biografiske skisser av de første amerikanske stasjonssjefene, den kontinuerlige betydningen av den diplomatiske salong og diplomatenes koner i Sverige. Her finnes det intervjubasert samtidshistorie, lettbente skisser og historiske nærstudier. Nysgjerrige lesere vil plukke opp morsomme anekdoter, og få innsikt i en rekke vidt forskjellige problemstillinger. De vil imidlertid ikke være i posisjon til å si noe særlig generelt om kvinner i verdens diplomati etter 1945. Noen spadestikk presenteres imidlertid. Kapittelet til Philip Nash gir en god oversikt over de tidlige politisk utnevnte kvinnelige ambassadørene i den amerikanske utenrikstjenesten og hvordan de bidro til å bane vei for kvinner som kom senere. Kapittelet til Nevra Biletkin om svenske diplomathustruer gir likeledes et godt bilde av en av de sentrale utfordringene for post-moderne diplomati: hvordan man skal tenke familie $\mathrm{i}$ en likestilt utenrikstjeneste.

To områder er imidlertid ikke dekket. For det første mangler det en diskusjon av kvinner i samtidige utenrikstjenester, komparativt eller med fokus på en enkelt utenrikstjeneste. Ettersom kvinnene har kommet sterkere og sterkere inn i mange lands diplomati de siste 40 årene, er det rett og slett vanskelig å forstå at en bok som denne ikke har noe å si om kvinner i diplomatiet i det 21. århundre. For det andre mangler både for den moderne, og i og for seg også for de tidligere periodene, en diskusjon av kvinner som statsledere. Det finnes en del berømte eksempler på regjerende dronninger, og i stadig større grad har kvinner de siste tiårene virket som statsledere og utenriksministre. I sin iver etter å vise frem de glemte eller ukjente kvinnene i diplomatiet, virker det rett og slett som om forfatterne har sett bort fra de «åpenbare» eksemplene.

På et mer overgripende nivå kunne både redaktørene og forfatterne med fordel ha hevet blikket litt oftere, og sett til andre fagtradisjoner og litteraturer. Noen av tekstene forholder seg som nevnt til den fremvoksende litteraturen om slektskap, men her ville det vært noe å hente for de aller fleste av forfatteren. På samme måte nevnes bidrag fra IR-faget i et par av de kapitlene som diskuterer relativt nye fenomener, men igjen er det rimelig å anta at innsikter fra for eksempel James Der Derian, Costas Constantinou og Iver B. Neumann ville ha vært nyttige for de fleste av forfatterne. De kunne i det minste ha bidratt til å gi boken et noe mer helhetlig preg. Slik det er nå, fremstår den som et svært viktig bidrag, men også med et stort uforløst potensiale.

\section{Kvinner i diplomatiet}

Helen McCarthys monografi om kvinner i og rundt det britiske diplomatiet er en mye mer helstøpt bok enn Sluga og James’ essaysamling. Fokuset er sterkere og tidsperioden som dekkes mye kortere; fra andre halvdel av 1800-tallet til dags dato. McCarthy er også en bedre forfatter enn de fleste av bidragsyterne til essaysamlingen, hun skriver lettlest og medrivende om store og små menneskeskjebner og lar på

${ }^{2}$ McCarthys kapittel overlapper i stor grad med boken hennes, som diskuteres nedenfor. 
virkningsfull måte øyeblikksbilder fra storpolitikken ramme inn fortellingen om kvinnenes svært gradvise inntreden i diplomatiet. Det aller mest slående med historien som presenteres, er nemlig hvor sakte det har gått for kvinner å få en plass i den britiske utenrikstjenesten. Full likhet i ansettelsespraksiser, opprykksmuligheter og tilnærmet likhet i familieplanlegging har først kommet de siste 20 årene. Denne trege utviklingen innebærer imidlertid en utfordring for McCarthy i at stofftilgangen er begrenset. Utfordringen forsterkes av at hun i tillegg har valgt å legge seg på en relativt nærsynt fortellende linje, uten noen systematisk diskusjon for eksempel av hvordan mer gjennomgripende samfunnsendringer påvirket kvinners mulighet $\mathrm{i}$ diplomatiet. De første to tredjedelene av boken faller i lange passasjer innen sjangeren «lives of remarkable women». Denne sjangeren behersker McCarthy meget godt, og det er uten tvil fortjent at hun har fått en populærvitenskapelig pris for boken. Helheten lider allikevel under at boken ikke har noen innledning som trekker opp linjene for undersøkelsen, og bare en kort epilog med spede forsøk på å løfte blikket. På sitt vis minner derfor også Women of the World om en essaysamling, med velskrevne portretter, men haltende sammenstilling.

De første kapitlene er viet tematikk vi kjenner igjen fra samlingen til Sluga og James, og diskuterer hvordan kvinnene, til tross for at de var usynlige i det sene 1800-tallets diplomati, allikevel var til stede overalt. Som i tidligere hundreår var det særlig som koner, mødre, døtre og søstre de kunne spille en rolle, og jo høyere opp i samfunnet de var, jo større var den potensielle rollen. Kongelige scoret naturligvis høyest, men en fordelaktig kone kunne ha stor betydning for en ung diplomats karrieremuligheter, og kunne være avgjørende for om man fikk en ambassadørstilling ved en av de sentrale europeiske ambassadene (44). Rapporter om diplomatenes koner lå faktisk ved personalfilene til mannlige diplomater frem til på 1980-tallet (45)!

Frem til første verdenskrig var kvinnene imidlertid kun rundt diplomatiet, det var først med krigen at enkelte spesielt begavede kvinner fikk plass i mer eller mindre offisielle diplomatiske posisjoner. Etter at krigen var avsluttet, ble denne erfaringen brukt som argument for at kvinner kunne og burde få adgang til utenrikstjenesten, og McCarthy bruker to kapitler på inngående diskusjon av argumentene for og mot kvinners inntreden i diplomatiet fra en sentral komité som virket i 1934. Som tidsbilde av hvor konservativ den britiske utenrikstjenesten og samfunnet den virket innen var, er disse kapitlene fascinerende lesning. Det er lett å tenke seg en tjeneste befolket av en krysning av karakterer fra P.G. Wodehouse og Downton Abbey, med lange blikk bakover og lite fantasi i sin vurdering av fremtiden.

Det måtte en verdenskrig, og enda flere eksepsionelle kvinner, til, før den britiske utenrikstjenesten ble åpnet for kvinner. Og, som McCarthy påpeker i en av ganske få overgripende kommentarer, var det endringer i samfunnet rundt utenrikstjenesten som til slutt presset frem endringene innen tjenesten (230). Men det spilte også en rolle at den andre verdenskrig normaliserte kvinner i diplomatiske roller i enda større grad enn den første hadde gjort. De aller fleste av motforestillingene fra komiteen fra 1934 hadde vist seg meningsløse i møte med kvinner som faktisk utførte diplomatiske oppgaver. En talende utveksling kom i komiteen som skulle vurdere kvinners deltagelse i diplomatiet igjen i 1946. Et konservativt medlem mente at hovedspørsmålet var «om 
kvinner hadde evner som gjorde dem skikket for utenrikstjenesten», men komiteens leder kontret umiddelbart, og understreket at spørsmålet heller var «om utenrikstjenesten er så spesiell at den ikke bør føye seg etter det grunnleggende prinsippet, som parlamentet har understreket, at kvinner og menn skal vurderes på lik linje i byråkratiet» (233). Kvinnene fikk adgang, men fortsatt var det mange land de ikke fikk tjenestegjøre i, med begrunnelse i opinionen i de respektive landene, og fortsatt var det et krav om at de måtte fratre ved giftemål, ettersom det var umulig å forestille seg at en mann kunne være diplomatisk ledsager. Rundt regnet kom det snart omtrent to prosent kvinner i det mest prestisjefylte karriereløpet (260).

En av grunnene til at det gikk sakte å få inn en større andel kvinner, var åpenbart regelen om at gifte kvinner måtte fratre, som ikke ble avskaffet før i 1973 (284). Og som i tiårene før var hovedutfordringen hva man skulle gjøre med den diplomatiske husbonden. I tillegg kom de diplomatiske barna. I tiårene som hadde gått siden kvinners deltagelse i diplomatiet først kom på banen, hadde klassesamfunnet endret seg ganske kapitalt. Da overklassens feminister argumenterte for at kvinner kunne delta i diplomatiet på samme måte som menn, så var det med visshet om nannies og hjelp i huset som var helt fremmed for kvinnene på 70-tallet (291). Ergo burde utenrikstjenesten ha vært forberedt på at også de diplomatiske hustruene ville kunne gjøre seg bemerket. Allikevel ble det en overraskelse når en yngre generasjon kvinner gift med diplomater krevde godtgjørelse og regulering av arbeidsoppgaver. Fortsatt var det også slik at enkelte posisjoner ble opplevd som vanskelige for kvinner å fylle, som når det ble understreket at kvinnelige diplomater i Helsinki var et problem, ettersom så mye av det diplomatiske samkvemmet der foregikk i sauna (275).

Kvinnenes fremgang i den britiske utenrikstjenesten fortsatte å være svært gradvis, inntil Robin Cook tok over som utenriksminister i Tony Blairs regjering i 1997. Deretter har det vært ganske stor formell likhet i tjenesten, om enn tradisjonelle praksiser og kjønnsrollemønstre viser seg vanskelige å se helt bort fra. McCarthy har trolig sitt på det tørre når hun hevder at kvinnenes muligheter til å gjøre suksess i diplomatiet har hatt mer å gjøre med endringer i generelle holdninger blant britiske ektemenn, enn med ny praksis i utenrikstjenesten (342).

McCarthy har skrevet en lettlest og engasjerende bok, men i hovedsak en populærvitenskaplig bok. Som hun selv påpeker, hadde hun ingen tidligere erfaring med diplomatisk historie før hun gikk i gang med dette prosjektet. Hadde hun hatt det, ville hun nok latt være å gjøre små feil som å plassere en britisk ambassadør på Island seksten år før britiske sendemenn til Island fikk den tittelen, og hun ville brukt mindre tid på selvfølgeligheter og mer tid på genuin analyse. Samfunnsanalysene fremstår nå stort sett som selvsagtheter, og det er få forsøk på å løfte blikket. McCarthy kan allikevel knapt unngå å skjele til hvordan kvinnene kom inn i den amerikanske utenrikstjenesten. Og her er det en del interessante forskjeller. Amerikanske kvinner fikk adgang til høyere posisjoner tidligere (98), og politisk utnevnte kvinnelige stasjonssjefer kom allerede før andre verdenskrig. Politisk utnevnte kvinner ble symboler, og synes å ha spilt en rolle både som oppmuntring for andre kvinner og for å bryte ned klisjefylt motstand mot kvinner i diplomatiet. Den politiske feminismen på 1960- og 70-tallet fikk også mer direkte nedslag i amerikansk utenrikstjeneste, der kvinnene organiserte 
seg $\mathrm{i}$ en egen interesseorganisasjon og brukte rettssystemet til å presse igjennom like muligheter langt tidligere enn i Storbritannia (303-305). De britiske kvinnelige diplomatene synes å ha vært mer opptatt av nasjon og profesjon, enn av kjønn, noe som trolig bidro til å sinke likestillingsprosessen i britisk utenrikstjeneste (285).

\section{Avslutning}

Så viser det seg altså at kvinnene har vært til stede i diplomatiet også, hele tiden. I stort burde ikke dette være noen overraskelse, men det særlig boken til Sluga og James viser, er at kvinnene ikke bare var til stede, de var i mange hundre år helt sentrale for det europeiske diplomatiet. En logisk konsekvens av den kunnskapen som bringes frem her, er at hele historien om fremveksten av det moderne diplomatiet må skrives om. McCarthys bok er ikke like banebrytende i stort, men den er allikevel viktig som den første av sitt slag. Med hennes bok som utgangspunkt bør det være mulig å skrive komparative analyser av hvordan kvinnene kom inn i ulike lands utenrikstjenester, og også å diskutere de nåtidige familieutfordringene for diplomatiet i relativt likestilte land.

Bøkene har det til felles at de gir gode, til dels glimrende, utgangspunkter for videre forskning, og at de absolutt bør inspirere. De plages imidlertid også begge av underskudd på strukturering, manglende blikk for det som foregår utenfor egen horisont og lite interesse for abstrahering eller teoretisering. Sterkere og klarere innledninger og avslutninger, som tok opp mer overgripende emner, ville ha hevet begge bøkene betraktelig. Når de allikevel i sum må vurderes som vellykkede, så skyldes det at de vekker nysgjerrigheten og får leseren til å se helt nye ting og en sentral institusjon på en helt ny måte. Og har man levert et intellektuelt prosjekt som klarer dette, klarer leseren godt å leve med de større og mindre skjønnhetsflekkene underveis.

\section{Litteraturliste}

Buzan, Barry \& George Lawson (2015) The Global Transformation. History, Modernity and the Making of International Relations. Cambridge: Cambridge University Press.

Fletcher, Catherine \& Jennifer Mara DeSilva (2010) «Italian Ambassadorial Networks in Early Modern Europe - An Introduction", fournal of Early Modern History 14 (6): 505-512.

Johnson, Christopher H., David Warren Sabean, Simon Tauscher \& Francesca Trivellato (red.) (2011) Transregional and Transnational Families in Europe and Beyond. Experiences Since the Middle Ages. New York: Berghahn Books.

Koselleck, Reinhart (1988) Critique and Crisis. Enlightenment and the Pathogenesis of Modern Society. Cambridge, Mass: MIT Press.

Leira, Halvard (2011) The Emergence of Foreign Policy: Knowledge, Discourse, History. PhD Dissertation, University of Oslo.

Leira, Halvard (2016) "Conceptual History of Diplomacy», i Costas M. Constantinou, Paul Sharp \& Pauline Kerr (red.) The SAGE Handbook of Diplomacy. London: Sage.

Mori, Jennifer (2010) The Culture of diplomacy. Britain in Europe, c. 1750-1830. Manchester: Manchester University Press.

Neumann, Iver B. (2012) «Euro-centric diplomacy: challenging but manageable», European fournal of International Relations 18 (2): 299-321.

Neumann, Iver B. (2013) Diplomatic Sites. A Critical Enquiry. London: Hurst.

Palonen, Kari (2006) The Struggle with Time: A Conceptual History of 'Politics' as an Activity. Hamburg: LIT Verlag.

Towns, Ann (2014) «Statens bemanning: Europeiske maskulinitetsidealer og det nye Norge», Internasjonal Politikk 72 (3): 389-404. 